\title{
USER EMBRACEMENT WITH RISK CLASSIFICATION: PERCEPTIONS OF THE SERVICE USERS OF AN EMERGENCY CARE UNIT
}

\author{
João Lucas Campos de Oliveira', Ana Paula Gatti², Mayckel da Silva Barreto³, José Aparecido Bellucci Junior', \\ Herbert Leopoldo de Freitas Góes ${ }^{5}$, Laura Misue Matsuda ${ }^{6}$
}

\footnotetext{
${ }^{1}$ Doctoral student, Postgraduate Program in Nursing (PSE), Universidade Estadual de Maringá (UEM). Contributing lecturer, Universidade Estadual do Oeste do Paraná. Cascavel, State of Paraná (PR), Brazil. Email: enfjoaolcampos@yahoo.com.br

${ }^{2}$ RN. Maringá, Paraná, Brazil. Email: paulinhagatti@hotmail.com

${ }^{3}$ Doctoral student, PSE/UEM. Professor, Faculdade de Filosofia, Ciências e Letras de Mandaguari. Maringá, Paraná, Brazil. Email: mayckelbar@gmail.com

${ }^{4}$ Doctoral student, PSE/UEM. Professor, Universidade Estadual do Norte do Paraná. Maringá, Paraná, Brazil. Email: bellucci@uenp. edu.br

${ }^{5}$ Ph.D. in Nursing. Professor, Department of Nursing, UEM. Maringá, Paraná, Brazil. Email: hlfgoes@uem.br

${ }^{6}$ Ph.D. in Nursing. Professor, Department of Nursing, UEM. Maringá, Paraná, Brazil. Email: lmmatsuda@uem.br
}

\begin{abstract}
Objective: to investigate the perception of service users of an emergency unit, regarding attendance based in User Embracement with Risk Classification.

Method: his descriptive-exploratory study, with a qualitative approach. The data were collected from 20 service users through an audiorecorded interview, guided by the following question: Tell me about your initial attendance, the user embracement with risk classification, which you received in this unit.

Results: content analysis was undertaken with the data in thematic modality, from which two categories resulted: Risk classification as an advantage in attending emergencies; and Disagreement with the risk classification established by the professionals. Although the service users perceived User Embracement with Risk Classification as a measure which optimizes attendance in emergencies, some users disagreed with the classification made by the professionals.

Conclusion: the objectives of User Embracement with Risk Classification need to be better publicized, with a view to the better acceptance of its results by society, as when classified as being of lower priority, the service users mention feeling unsafe and dissatisfied.

DESCRIPTORS: User embracement. Triage. Emergency medical services. Nursing.

\section{ACOLHIMENTO COM CLASSIFICAÇÃO DE RISCO: PERCEPÇÕES DE USUÁRIOS DE UMA UNIDADE DE PRONTO ATENDIMENTO}

\section{RESUMO}

Objetivo: apreender a percepção de usuários de uma unidade emergencial sobre o atendimento embasado no Acolhimento com Classificação de Risco.

Método: estudo descritivo-exploratório, de abordagem qualitativa. Os dados foram coletados junto a 20 usuários por meio de entrevista gravada, norteada pela questão: Fale-me sobre o atendimento inicial, o acolhimento com classificação de risco, que o(a) $\mathrm{Sr}(\mathrm{a})$ recebeu nesta unidade.

Resultados: realizou-se análise de conteúdo dos dados, modalidade temática, da qual resultaram duas categorias: A classificação de risco como vantagem no atendimento às emergências; e Discordância com a classificação de risco estabelecida pelos profissionais. Apesar de os usuários perceberem o Acolhimento com Classificação de Risco como meio que otimiza o atendimento em emergências, houve quem discordasse da classificação atribuída pelos profissionais.

Conclusão: o Acolhimento com Classificação de Risco necessita de maior divulgação de seus objetivos visando a melhor aceitação de seus resultados pela sociedade, pois quando classificados como de menor prioridade, os usuários referem insegurança e insatisfação.

DESCRITORES: Acolhimento. Triagem. Serviços médicos de emergência. Enfermagem. 


\section{RECEPCIÓN CON CLASIFICACIÓN DE RIESGO: PERCEPCIONES DE LOS USUARIOS DEL ATENCIÓN DE EMERGENCIA}

RESUMEM

Objetivo: aprehender la percepción de los usuarios de una unidad de emergencia en el Centro de recepción con Calificación de Riesgo.

Metodo: estudio exploratorio descriptivo con abordaje cualitativo Se recolectaron datos de 20 usuarios a través de entrevistas grabadas, guiado por la pregunta: Coménteme sobre la recepción inicial con calificación de riesgo, que usted recibió en esta unidad.

Resultados: se realizó análisis de contenido con la modalidad temática, lo que resultó en dos categorías: La clasificación de riesgo como una ventaja en la respuesta a emergencias y; desacuerdo con la clasificación de riesgo establecida por los profesionales. Aunque los usuarios percibieron la Recepción con Calificación de Riesgo como un medio para optimizar la atención de emergencia, se identificaron también algunos usuarios que no estuvieron de acuerdo con la calificación otorgada por los profesionales.

Conclusión: el Recepción con Calificación de Riesgo requiere una mayor divulgación de sus objetivos con el fin de mejorar la aceptación de sus resultados por parte de la sociedad, porque cuando se ha clasificado con una prioridad más baja, los usuarios refieren inseguridad e insatisfacción.

DESCRIPTORES: Acogimiento. Triaje. Servicios médicos de urgencia. Enfermería.

\section{INTRODUCTION}

The demographic, social and epidemiological transition causes the supply and demand for health services in Brazil to be a constantly changing phenomenon. In this context, in recent decades, a large increase has been observed in the demand upon the urgent and emergency services ${ }^{1}$ which, in their turn, require a large increase in technology created in different areas and forms.

As a result of the specific character of the dynamic of the attendance provided, as well as of the actual needs of the population which seeks the emergency services, in Brazil, in 2003, the structuring and functioning of the Emergency Care Units (UPA) were initiated, through the National Policy for Emergency Medical Care. These units are configured as establishments of the emergency care network, with intermediate complexity, with uninterrupted functioning and competence to embrace and provide care to service users with an acute clinical situation of any nature. ${ }^{2}$

The UPAs are health services which require greater attention from the three spheres of government (municipal, state and federal), as they are an important gateway for the service user in the Unified Health System, for attendance to urgent and emergency situations. Even so, it may be observed that these services suffer from daily overloading with patients, caused mainly by: the poor interaction between primary, specialized and hospital care; shortage of human resources; unpredictability of the demand and; the high number of cases of patients who are in serious conditions. ${ }^{3}$

In the light of the specific characteristics of the population seeking assistance, and of the problems experienced in the UPAs, it is not effective to prioritize attendances by order of arrival - making it essential to establish clinical criteria for classification and evaluation of the service users to be attended. ${ }^{4}$ Therefore, in 2004, the Ministry of Health established the National Humanization Policy ('HumanizaSUS'), which, among its directives, proposes the restructuring of the Urgent/Emergency Services, through the implementation of User Embracement with Risk Classification and Assessment (ACCR). ${ }^{5}$

ACCR aims to reorganize the care, through embracement of the service user and prioritization of the attendance according to the severity of the risk or situation presented, so as to systematize the attendance such that this may be faster, safer, and more humanized. ${ }^{5}$ This system presents advantages because it controls demand, optimizes the attendance to urgent and emergency cases, reduces the occupational overload of the health team and strengthens the service user-worker bond. ${ }^{6-7}$

In the attendance through the ACCR, after the user has been embraced in the service, use is made of stratified ordering in the form of a minimum of four colors for classifying the health issues: red (emergency); yellow (urgent); green (less urgency); and blue (not urgent). Respectively, these represent the scale from greater to lesser risk, according to clinical criteria established by institutionalized protocols. ${ }^{5}$ Furthermore, the emergency services can adopt systems with other categories for attendance, as in the example of the Manchester Triage System, which is much used worldwide and which adds the color 'orange' for those patients classified as "very urgent", that is, an intermediate stage between the colors red and yellow mentioned above. ${ }^{8}$

In relation to the benefits aimed for by the ACCR, although scarce, the literature indicates difficulties for its effective implementation and operationalization, due to the high number of service users who seek urgent/emergency attendance but 
who present clinical situations which could be resolved in primary care, the need for contracting more nursing professionals to work at peak hours, and the need for investment for adjustment of the environment. ${ }^{9}$ In addition to this, from the service users' perspective, there is a need to establish permanent pacts between the services and the community. ${ }^{10}$

As this is a contemporary, socially constructed process, the need is evidenced for studies on the ACCR in the services which have implanted this system in their care routine, because the results of studies could provide a basis for the (re-)planning of the system so as to promote the humanization and quality of the care. In this regard, it is important to obtain information from the health service users who use ACCR, due to the fact that the same are the active subjects of its (re)construction and validation. ${ }^{11}$

Based in the above, the question is raised: what is the perception of health service users regarding the attendance received in an UPA in which ACCR has been implanted? And, in order to answer this question, in the present study the objective is proposed to investigate the perception of users of an emergency unit regarding attendance based on the system of User Embracement with Risk Classification.

\section{METHOD}

This is descriptive, exploratory research with a qualitative approach, undertaken with 20 users of an UPA in a municipality in the interior of the Brazilian state of Paraná, in the months of November and December 2013. The service investigated used the Manchester Triage System protocol, linked to the stage of risk classification of the routine ACCR system.

The people who participated in the study were aged 18 years old or over; they had received attendance through ACCR; and they had not been given a risk classification of red, as this clinical condition would have made it impossible for the subject to participate in the study.

Data collection was undertaken through audio -recorded interviews, in a private space in the UPA itself, guided by the following question: Tell me about the initial attendance, the user embracement with risk classification, which you received in this unit. The search for information continued until theoretical saturation of data, that is to say, the point at which the researcher noted that the accounts had become repetitive.
The interviews were transcribed in full, following which the texts were revised in relation to spelling, without the essential meaning being changed. Following this, the information was subjected to treatment and analysis, through the technique of content analysis (thematic modality), respecting the stages of pre-analysis, exploration of the material, treatment of the data and inference from the results. ${ }^{12}$

In the pre-analysis, skim reading was undertaken of the printed interviews, emphasizing the points of interest, followed by exploration of the material through thorough and exhaustive reading of the entire content. Following that, the codification of the messages was undertaken, through which the nuclei of meaning were grasped, which were grouped, giving rise to the thematic categories. Once the categorization had been finished, inference from the data obtained was undertaken. In this phase, the context of the language, the condition of the issuer, and its meanings were analyzed. ${ }^{12}$

In the presentation of the results, the excerpts from the accounts were edited, removing or adding terms (between brackets) which facilitated the understanding by the reader without, however, changing the content. With a view to maintaining the interviewees' confidentiality, the letter ' $U$ ' was placed at the end of the excerpts, representing "User", followed by an Arabic numeral indicating the chronological sequence of the interview held.

This study was undertaken in accordance with the requirements stipulated in Brazilian National Health Council (CNS) Resolution N. 466/2012, and was documented under Certificate of Ethical Consideration N. 22632013.3.0000.0104, established after analysis and issuing of a favorable decision (449.662) by the Standing Committee for Ethics in Research involving Human Beings, of the State University of Maringá.

\section{RESULTS AND DISCUSSION}

The study participants' ages varied from 18 to 57 years old (mean of 33 years); the majority were female (13); single (13); and had sought some form of attendance in an UPA on a previous occasion (15).

After the analytical treatment of the data, two categories emerged: a) Risk classification as an advantage in attending emergencies; and b) Disagreement with the risk classification established by the professionals. 


\section{Risk classification as an advantage in attending emergencies}

In this category, the service users reported that the systematic use of the ACCR system could accelerate the attendance for patients with clinical situations considered serious: Because they always use this classification system, they [the health professionals] understand what the person is feeling better, and if the person is at greater risk, they move them on faster. I think this is great! (U3). The risk classification is good, because you can know, more or less, what time you're going to be seen at. The higher the risk, the faster you are seen (U7).

According to the above-mentioned accounts, it is surmised that the waiting time for those service users who present what might be called "greater risk" is something that can be optimized through the use of the ACCR, and this is important and necessary, as the waiting time is a factor which cannot be disassociated from, and which is inversely proportional to, the possibility of stabilizing the risk or acute situation presented by the patient. ${ }^{13}$

Besides the optimized waiting time for those who present clinical situations considered more serious, the ACCR system also serves as a support such that the professionals, through the classification and monitoring of each user's risk, can provide information on the time foreseen until each is attended - including those who, depending on their classification, present less serious clinical situations. ${ }^{5}$ This is also important, as when they are properly informed regarding the time which they will have to wait before they are attended, the users and/or their family members may feel less anxious and more secure.

Corroborating what has been stated above, one study regarding the implantation of ACCR in emergency services indicates that this system makes it possible to inform the service user of the time at which they can expect to be seen and the waiting time, thus promoting reduction in anxiety and an increase in the level of client satisfaction. ${ }^{10}$ In this regard, it is understood that attendance based on the ACCR may be considered to be a factor which contributes to achieving quality care, given that the level of users' satisfaction is known to be one of the principal quality indicators in the area of health. ${ }^{14}$

In emergency units, the organization of the multi-professional team's work process is an element which influences the quality of the care provided, as the way in which the work process is organized is reflected in the care results. ${ }^{4}$ In this way, in emergency services, the organization of the work can be improved through the use of a set of protocols and systems which aim to embrace, classify and direct the service user for the attendance, in a fast, safe and humanized way, ${ }^{15-16}$ as the ACCR establishes.

Other participants also recognized that the ACCR classification can optimize the time until attendance of those who present a greater risk of death. It is an advantage for somebody who is at greater risk, because they will be seen first. I think this is important because there are people who are not in such a lot of pain, and there are other people who are at risk of dying [...] I think this thing is great (U20). I think that this has improved the attendance. Sometimes people come along who are very ill and who need to be attended, and you can't have them waiting for a long time. That's why I think this is an improvement (U9). I certainly do think that you have to use this classification! If a person comes along who is very ill, and I'm in front of them, should I be seen first? Of course you have to be classified (U10).

According to the excerpts, the interviewees show understanding and agreement with the application of the ACCR, in particular in relation to situations with greater clinical severity. This data is important and necessary, as - because it deals with users in an emergency state - speed of attendance is an important factor in saving their lives and preventing sequelae.

The perception presented by the interviewees corroborates the literature ${ }^{17}$ which mentions that the service users normally understand that emergency cases must have prioritized attendance. On the other hand, although the ACCR favors the optimization of attendance for more serious cases, in the service users' opinion, other important objectives which should be associated with the system, such as embarrassment and the humanization of the care, continue to be little present. ${ }^{17}$

Faced with the results presented, it is conjectured that the fact that the service users interviewed did not mention embracement, still less humanization, which should be associated with the ACCR system, is important. This gains yet more relevance when it is observed in studies undertaken with health professionals regarding the system that ACCR has greater impact on the routine care only in relation to the risk classification actions, it being the case that embracement and humanization, in these subjects' perception, although recognized as important, are often conceived of as secondary activities. ${ }^{6,18}$ This being the case, it is necessary that the 
consolidation of the embracement, culminating in the humanization of the care, should be a product of a continuous process of reflection and action among users, professionals and health managers.

Overcoming the limits of personal attendance, one interviewee indicated the importance of risk classification for the fast attendance to other persons, indicating that this system, in the context studied, may be passing through a period of social legitimation, regarding its characteristic of ordering the care by risk: Sometimes we turn up here with a child with a high fever, and there is another child who doesn't need to be seen so urgently. The child with fever has to be seen first. This is why I think it is good, because if somebody needs to be seen urgently, they are sent straightaway (U16).

The perception that attendance is faster depending on the seriousness of the clinical case presented by the patient, or even by her family member, was also observed in one study undertaken in the South region of Brazil, with users of health units which used the ACCR system. ${ }^{10}$ In that study, the results corroborated the system's proposal, as it was observed that attendance based on risk must be the method used for establishing order in the emergency services.

Other Brazilian studies undertaken with physicians and professionals from the nursing team have also corroborated the above, indicating that - in the health professionals' perception - the characteristic understood best and accepted most by the users in relation to ACCR is the immediate offering of attendance for those cases understood as the most urgent. ${ }^{6-7,18}$

The participants in the present investigation did not mention the possible advantages arising from use of ACCR, such as, for example, better control of the demand, strengthening of the service user-worker bond, and greater professional security in undertaking the activities, , ,7,9 which may partly be explained by the fact that the system has been instituted in the unit studied for only one year. As a result, it is surmised that service users still lack information and have not adapted to the ACCR's method of attendance. It is possible that this is one of the factors which influences their ability to list a greater number of advantages.

Possibly due to the reasons referred to above, some interviewees mentioned a certain dissatisfaction resulting from the disagreement between the risk established by the UPA professional and the risk that the service user thought or felt that they had.

\section{Disagreement with the risk classification established by the professionals}

In this category, the grouping of the participants' accounts indicated that in spite of the ACCR having the potential to organize/optimize attendance to emergency cases, when the classification is one's own, some service users do not agree with the risk established by the health professionals: [...] I came here today poorly, and they put me down as 'green' classification. I, on the other hand, from my point of view, thought that my classification was 'yellow', because I was not very bad, but equally I was not very well. I think that the classification which they made is rather bad [...] (U1). This classification is great, but really, I think that they should evaluate better, because I arrived here in a lot of pain and they put me down as 'green'. They gave very low priority to what I was feeling. Therefore, they should give priority because of what the person is feeling, and not because of what they think it is (U8). There is a woman who is ill over there, and she hasn't even been seen yet. Her blood pressure is low, she's nearly falling off the chair, and you can be sure that she is classified as 'green', that she is not at risk (U5).

The excerpts presented are important, as in spite of the risk classification being based on previously established clinical criteria, ${ }^{5}$ each one seeks the resolution of individual problems which are perceived uniquely, involving their subjectivity, which cannot always be evaluated safely by the professional. As a result, the measuring or classification of problems relating to health is something which is difficult to evaluate objectively, especially regarding the feeling of acute pain. ${ }^{19}$ It may be that one way of resolving this impasse could be the use of pain scales, which can be measured through numbers with different gradations, or figures. Other measures which could minimize distortions of this type are linked to the embracement and humanization actions, also proposed in the ACCR system.

Another issue which deserves to be emphasized is related to the fact that the service users who revealed that they disagreed with the classification undertaken through the use of the ACCR system were those classified as 'green', which represents a situation of less urgency ${ }^{5}$ and, possibly, could be resolved in the ambit of primary care. ${ }^{9,16}$ However, due mainly to the lack of operationalization of the referral and counter-referral system, and to the hegemony of the medical-curativist model, the service users who could be attended in low-complexity services seek the resolution of their problems in emergency services. ${ }^{20}$ 
In the light of the findings and the literature consulted, it is perceived that ACCR is still in an initial phase of its concretization, as the users still indicate the system's efficiency basically for emergency cases, feeling discontent and/or discredited as a result of their classification as of lower risk. In addition to this, the fact that they did not mention the aspects inherent to embracement and humanization of the care contributes to the maintenance of the culture that the system has the function of mere "triage", as can be observed in the following excerpt: today I was only seen fast because there weren't many people here. Because my classification was 'green', but I was not well, I was in quite a lot of pain, I think that the people who work here should do training so that they can do triage better (U2).

U2's account characterizes the possible difficulty that service users have in overcoming the logic of "triage", which is considered an excluding method, as it has as its characteristic to "choose" who shall or shall not be attended, failing to assist those who, according to the method of "triage" itself do not meet the requirements established in it. ${ }^{5}$ This being the case, the acceptance of the proposal of ACCR by society is important because it tends to avoid the overloading in the emergency services and, as result, to prioritize more serious cases with greater effectiveness.

In the light of the above, it may be perceived that ACCR, due to its characteristic of organizing the work, is also a system for managing the care - and that because of this it must be continuously improved and adjusted to the context of each service and/or clientele. ${ }^{19}$ It may be that one way of adjusting the ACCR to the population's needs is to instrumentalize the nurses, given that the actions for evaluating and classifying each case must be undertaken by this professional, who is considered qualified and prepared to work in the emergency services. ${ }^{21-22}$

It is important to emphasize that the nurses who work in such services, who adopt ACCR in their care routine, need to continuously improve their knowledge and skills such that the classification and evaluation actions may be efficient and efficacious. Behaviors of this type are fundamental for avoiding what occurred with one of the service users, who mentioned that the classification received had not been appropriate and that this had nearly resulted in harmful and even irreversible consequences. I believe that this doesn't work. I can cite an example which happened with me. I came to the UPA and they classified me as "orange". They told me to wait. So - what is the priority here? Do you know what my problem was? I went to the cardiologist, and I had $90 \%$ of the main vein blocked. I had to do an urgent angioplasty, in a hurry, so as not to die. Yet here, they had classified it as a simple muscle pain (U4).

The excerpt presented reinforces the idea that, in the participants' understanding, the risk perceived individually diverges from the risk classified according to the ACCR, which - on this occasion - was inefficient, as it was rapidly necessary to seek more complex services in order to resolve the issue in question. This is relevant, as, in isolation, the ACCR does not guarantee improvement in the quality of the care. On the contrary, if the service user referred to another service were not embraced, she would be excluded by the care network and, in many cases, her problem could be worsened. ${ }^{23}$

U4's account is related to the results of an evaluative study on ACCR, which revealed that a large proportion of the users left the emergency services without their problems or health issues being attended to the extent that they had expected. ${ }^{17}$ In order to confront this problem, it is essential that the managers of these services, and of primary health care, should construct agreed protocols, which ensure the effective implementation of the referral/ counter-referral system between the institutions and health networks.

The distrust or discontentment experienced by the users interviewed in relation to ACCR, such as that identified in U4's account, reaffirm aspects indicated in studies about this system's implantation, which indicate the need for performing some stages which are considered fundamental for the success of its operationalization, such as the contracting of more nursing professionals in the service, agreement among the emergency and non-emergency services, specific training for professionals who work with ACCR, the construction of the attendance protocols, based in the epidemiological profile of the population and the scientific literature. ${ }^{9,20}$

In the service studied, it was not possible to perceive whether such stages - inherent to the implantation of ACCR - were followed. However, it is a fact that being immersed in a specific work process, the system should be cyclically improved through actions involving (re)planning, action and evaluation.

In no interview was the behavior of embracement mentioned, which should be linked to actions of risk classification. ${ }^{5}$ This is an aggravating factor, because embracement and a disposition to listen are requirements for initiating an empathetic 
relationship with the service user and, in this way, ensuring a humanized process of risk classification, with greater access to the health services and achieving the central objective, which is qualified care. ${ }^{24}$

It is considered that, when the creation of a bond between workers and service users does not occur, there is a shortcoming in the relationship of empathy and extended general practice for the attendance, and this means that the precepts of the humanization of the care are not being valued. ${ }^{9}$ In the light of this fact, it is emphasized that it is necessary to discuss the best way of establishing a resolutive flow of attendance, in such a way that it is possible to keep the focus on the user's needs, considering, at the same time, the profile of the urgent and emergency service itself, and each institution's managerial context.

In the light of the above, it is perceived that the service users interviewed do not feel completely satisfied with the ACCR, given that they indicate the existence of efficacy only for emergency situations. This being the case, it is appropriate to reflect on the work of the multi-professional team in the care provision spaces such as the UPA, and on the use of the ACCR system, given that the quality of the care in these services is the product resulting among other things - from the sum of the actions of embracement, risk classification and directing of flows, associated with the professionals' relational, communicative and technical skills.

\section{CONCLUSION}

In this study, the perceptions of the users of an UPA regarding ACCR were represented in two thematic categories. The first, Risk classification as an advantage in attending emergencies, was configured by the grouping of the service users' reports which expressed that the ACCR is a system which is capable of adding speed to the attendance for those in emergency situations, that is, at risk of death.

In its turn, the second thematic category, Disagreement with the risk classification established by the professionals, grasped the subjects' perceptions referent to the ACCR's lack of accuracy for classifying the risk which the user attributed to him- or herself. It is concluded that although the ACCR is recognized as a valuable instrument in prioritizing cases considered to be serious, it needs better explanation to, and acceptance by society, because when they were classified as having lower priority for attendance, the service users mentioned feeling unsafe and dissatisfied.
The perception of service users in a single locale and at a single time is considered to be a limitation of the study. As a result, investigations of the longitudinal type and with a quantitative approach are suggested, having as the study object the assessment of service users and workers regarding the ACCR - and also the precision/accuracy of the classification made by the professionals.

Finally, as contributions to the area of health and of nursing, emphasis is placed on the information raised which certainly will provide a basis for further studies and discussions which aim for improvement of the ACCR instrument, in the search for results which promote the quality of attendance in the emergency services.

\section{REFERENCES}

1. O'Dwyer G, Oliveira SP, Seta MH. Avaliação dos serviços hospitalares de emergência do programa QualiSUS. Cienc Saúde Colet. 2009; 14(5):1881-90.

2. Ministério da Saúde (BR). Portaria n. 2.648, de 7 de novembro de 2011. Dispõe sobre as diretrizes para implantação do componente Unidade de Pronto Atendimento (UPA 24h) e do conjunto de serviços de urgência 24 h da Rede de Atenção às Urgências, em conformidade com a Política de Atenção às Urgências. Brasília. [Internet] 2011 [[cited 2014 Jan 18]. Available from: http://bvsms.saude.gov.br/bvs/saudelegis/ gm/2011/prt2648_07_11_2011.html

3. Jorge VC, Barreto MS, Ferrer ALM, Santos EAQ, Rikkli HC, Marcon SS. Equipe de enfermagem e detecção de indicadores de agravamento em pacientes de prontosocorro. Esc Anna Nery. 2012; 16(4)767-74.

4. Garlet ER, Lima MADS, Santos JLG, Marques GQ. Organização do trabalho de uma equipe de saúde no atendimento ao usuário em situações de urgência e emergência. Texto Contexto Enferm. 2009; 18(2):266-72.

5. Ministério da Saúde (BR). Secretaria de Atenção à Saúde. Política Nacional de Humanização da Atenção e Gestão do SUS. Acolhimento e classificação de risco nos serviços de urgência. Brasília (DF): MS; 2009.

6. Zanellatto DM, Dal Pai D. Práticas de acolhimento no serviço de emergência: a perspectiva dos profissionais de enfermagem. Ciênc Cuid Saúde. 2010; 9(2):358-65.

7. Costa MAR, Cambiriba MS. Acolhimento em enfermagem: a visão do profissional e a expectativa do usuário. Ciênc Cuid Saúde. 2010; 9(3):494-502.

8. Pinto Júnior D, Salgado PO, Chianca TCM. Predictive validity of the Manchester Triage System: evaluation of outcomes of patients admitted to an emergency department. Rev Latino-Am Enfermagem [Internet] 2012 [cited 2017 Set 29]; 20(6):1041-7. Available from: http://www.scielo.br/pdf/rlae/v20n6/05.pdf

9. Bellucci Junior JA, Matsuda LM. Implantação do Programa Acolhimento com Classificação e Avaliação 
de Risco e uso do Fluxograma Analisador. Texto Contexto Enferm [Internet]. 2012 [cited 2014 Jan 18]; 21(1):217-25. Available from: http:/ / www.scielo.br/ pdf/tce/v21n1/a25v21n1.pdf

10. Nonnenmacher CL, Weiller TH, Oliveira SG. Opiniões de usuários de saúde sobre o acolhimento com classificação de risco. Rev Eletr Enf [Internet]. 2012 [cited 2014 Jan 18]; 14(3):541-9. Available from: http:/ / www.fen.ufg.br/revista/v14/n3/v14n3a10.htm.

11. Vituri DW, Inoue KC, Bellucci Junior JA, Oliveira CA, Rossi RM, Matsuda LM. Welcoming with risk classification in teaching hospitals: assessment of structure, process and result. Rev Latino-Am Enfermagem [Internet] 2013 [cited 2014 Jan 18]; 21(5):1179-87. Available from: http://www.scielo. br/pdf/rlae/v21n5/0104-1169-rlae-21-05-1179.pdf

12. Bardin L. Análise de conteúdo. São Paulo (SP): Edições 70; 2011.

13. Martins HS, RA Brandão Neto, A Scalabrini Neto, I Velasco. Emergências clínicas - abordagem prática. $9^{a}$ ed. São Paulo (SP): Manole; 2014.

14. Pena MM, Melleiro MM. Degree of satisfaction of users of private hospital. Acta Paul. Enferm. 2012; 25(2):197-203.

15. Neto GV. Organização e funcionamento dos serviços de saúde - pronto socorro. In: Neto GV, Malik AM. Gestão em saúde. Rio de Janeiro (RJ): Guanabara Koogan; 2012.

16. Ulbrich EM, Mantovani MF, Balduino AF, Reis BK. Protocolo de enfermagem em atendimento emergencial: subsídio para o acolhimento às vítimas. Cogitare Enferm. 2010; 15(2):286-92.
17. Guedes MVC, Henriques ACPT, Lima MMN. Acolhimento em um serviço de emergência: percepção dos usuários. Rev Bras Enferm. 2013; 66(1):31-7.

18. Zem KKS, Montezeli JH, Peres AM. Acolhimento com Classificação de Risco: concepção de enfermeiros de um pronto socorro. Rev Rene. 2012. 13(4):899-908.

19. Coutinho AAP, Cecílio LCO, Mota JAC. Classificação de risco em serviços de emergência: uma discussão da literatura sobre o sistema de triagem de Manchester. Rev Med Minas Gerais. 2012; 22(2):188-98.

20. Fernandes FSL, Lima BS, Ribeiro MN. Welcoming with risk classification in the Hospital São Paulo's emergency department. Acta Paul Enferm. 2012. 25(Spe 2):164-8.

21. Souza RS, Bastos MAR. Acolhimento com classificação de risco: o processo vivenciado por profissional enfermeiro. Rev Min Enferm. 2008; 12(4):581-6.

22. Acosta AM, Duro CLM, Lima MADS. Atividades do enfermeiro nos sistemas de triagem/classificação de risco nos serviços de urgência: revisão integrativa. Rev Gaúcha Enferm. 2012; 33(4):181-90.

23. Rossaneis MA, Haddad MCL, Borsato FG, Vannuchi MO, Sentone ADD. Caracterização do atendimento após implantação do acolhimento, avaliação e classificação de risco em hospital público. Rev Eletr Enferm [Internet] 2011 [cited 2014 Jan 18]; 13(4):648-56.

24. Souza CC, Toledo AD, Tadeu LFR, Chianca TCM. Classificação de risco em pronto-socorro: concordância entre um protocolo institucional brasileiro e Manchester. Rev Latino-Am Enfermagem [Internet] 2011 [cited 2014 Jan 18]; 19(1):[08 telas] Available from: http://www.scielo.br/pdf/rlae/ v19n1/pt_05.pdf 